Quebec Cooperative Study

of Friedreich's Ataxia

\title{
Friedreich's Ataxia 1980 An Overview of the Physiopathology
}

\author{
ANDRÉ BARBEAU
}

SUMMARY: Phase three of the Quebec Cooperative Study' of Friedreich's Ataxia was devoted to an understanding of the physiopathology of individual symptoms on the basis of previously discovered biochemical leads. The present paper attempts to pull these results together by' presenting, as a hypothesis, a unifying scheme of possible interactions and relationships. The central core of this hypothesis is the demonstration in Friedreich's ataxia of a state of mitochondrial energy deprivation. This is indirectly responsible for such associated and important symptoms as muscle weakness, dying-

RÉSUMÉ: La Phase Trois de l'Étude Coopérative Québecoise sur l'Ataxie de Friedreich fut consacrée à la compréhension de la physiopathologie des sympiomes individuels sur la base d'observations biochimiques préalables. Le présent article tente une synthèse de c'es résultats en présentant, sous la forme d'une hypothèse. un schéma unificateur des interactions et relations possibles. Le point central de cette hypothèse est la démonstration dans l'ataxie de Friedreich d'un état de déprivation énergétique mitochondrial. Cette situation est directement responsable des symptomes associés tels faiblesse musculaire. neuropathie type "dying-back", k.pho-scoliose et cardiomyopathie hypertrophique. Secondairement, et possible- back neuropathy, scoliosis and hypertrophic cardiomyopathy. Secondarily, and possibly as an independent but linkedevent, the entry of glucose into cells and puruvate oxidation, are slowed down. favoring the development of diabetes. As a consequence, tissue concentrations of glutamic acid and aspartic acid are decreased, particularly in more vulnerable areas such as the cerebellum, brain stem and dorsal root ganglia. This tissue deficiency in putative excitatory neurotransmitters is directly responsible for the symptom of ataxia. This conclusion is reinforced $b y$ ' the correction of the ataxia in

ment même en tant qu'événement indépendant mais lié, l'entrée cellulaire du glucose. et loxydation du pyruvate, sont ralenties, favorisant un diabète chimique, puis clinique. En conséquence, les concentrations tissulaires en acide glutamique et acide aspartique sont considérablement diminuées, surtout dans les régions les plus vulnérables (telles le cervelet, le tronc cérébral et les ganglions dorsaux). Cette déficience tissulaire en acides aminés possiblement agissant comme neurotransmetterus excitateurs est directement responsable du symptome "ataxie". Cette conclusion est renforcée par l'observation que chez certains animaux expérimentaux, le symptome ataxie est complètement aboli par l'injection intraventriculaire de gluta- experimental animals, by the intraventricular injection of the same amino acids, and not by the injection of other stimulants of motricity. The observed mitochondrial energ. deprivation could be the metabolic consequence of major changes in the linoleic acid (18:2) composition of inner mitochondrial membrane phospholipids, such as cardiolipin. Such decreases in membrane 18:2 could be the result of interference with the normal incorporation of this fatty acid to lipoproteins and/or cell membranes. It is at this level that the search for the specific enzl'me defect in Friedreich's ataxia is continuing.

mate et surtout d'aspartate et non par celle d'autres stimulants de la motricité. La déprivation énergétique mitochondriale observée pourrait être la conséquence métabolique de changements majeurs dans la composition en acide linoléique (18:2) des phospholipides de la membrane interne des mitochondries, particulièrement de la cardiolipine. Un tel déficit en 18:2 membranaire peut résulter d'une interférence avec l'incorporation normale de cet acide gras aux lipoprotéines et/ou aux membranes cellulaires. C'est à ce niveau que ce concentrent nos recherches pour identifier le défaut enzl'matique spécifique dans l'ataxie de Friedreich. 


\section{CLINICAL ASPECTS}

November 1980 marks the sixth year of operation of the Quebec Cooperative Study of Friedreich's Ataxia, and already considerable progress has been made in the understanding of the disease, through the unfailing efforts of more than one hundred direct contributors and the invaluable contributions of many internationally recognized experts who served as consultants or part time collaborators. It can be recalled that during phase one of this investigation, we studied systematically diverse metabolic pathways in 50 ataxic patients. This led to a strict clinical delineation of the disease (Geoffroy et al, 1976) which has now been adopted as a useful working definition in most countries, in that patients answering to these strict criteria, will always be accepted as suffering from "typical Friedreich's ataxia". The other consequence of this systematic metabolic survey during phase one, was the delineation of a number of biochemical leads to the etiology or pathophysiology of the disease (Barbeau, 1976) which were then methodically examined during parts one and two of phase two (Barbeau, 1978, 1979). Some apparently important leads turned out to be artefacts or secondary aspects. Others could not be confirmed. Still others have led to detailed further investigations which, we feel, are taking us closer to the eventual primary event, and have stimulated a wealth of new research in the field of ataxia. After 6 years, it is now time to attempt to review our present understanding of the pathogenesis of the symptoms of Friedreich's ataxia, and this is the purpose of the present paper.

One of the most important steps in the process of discovery, is the confirmation by independent researchers of the initial observations, employing identical methods. The scientific steering committee, recognizing the need for this step and cognicent of the remarks by others that many of our previous findings could be due to the homogeneity and high consanguinity rate of the French Canadian population, asked a number of foreign investigators to repeat the same biochemical survey of their own patients. Again, in the present issue, we will find the results of this International Cooperation (see D'Angelo et al; Bertagnolio et al, the above two papers through the courtesy of the Italian Journal of Neurological Sciences; Campanella et al; Azari et al, this issue). Thus, it will be shown that using the same clinical definition for their patients, Italian investigators confirm the presence of "abnormal pyruvate responses" in a significant proportion of their patients (D'Angelo et al, this issue) and that others also find high bilirubin values in $20 \%$ of their Friedreich patients (Campanella et al, this issue; Kark and RodriguezBudelli, 1979). However, it should be mentioned that D'Angelo et al (this issue) found high bilirubin in only one of their 14 ataxic subjects, while an independent study in England (Walker et al, 1980a) failed to find any patient with this trait in a more heterogenous group of ataxics. The other findings of Phase One have also been confirmed by our Italian collaborators. Thus, diabetes is present in roughly a third of the patients (Campanella et al, this issue; Bertagnolio et al, this issue), and serum triglycerides, although within the normal range, are significantly higher than age and sex-matched "normal" controls. The possible discrepancy with the findings of Walker et al (1980a) is probably due to the use of "neurological" instead of "normal" control subjects by these authors.

In the course of this investigation into the problems of spinocerebellar degeneration, a number of new entities or variants have been recognized, particularly in isolated geographic areas. Until biochemical markers are identified and can be tested in the field, we feel it is more prudent to give these variants geographic names which identify and take into account the genetic and geographic factors present in these isolates. Thus we have previously defined "the CharlevoixSaguenay" Syndrome of recessively inherited spastic ataxia (Bouchard et al, 1978), the "Matane" recessive type of olivo-ponto-cerebellar atrophy (Barbeau, 1980), the "Gaspé type" of OPCA (Wastiaux et al, 1978), the "Acadian type" of recessive ataxia (Barbeau, 1980) and now a new form of recessive ataxia with severe amyotrophy in New Brunswick (Bouchard et al, this issue). Similarly, because it appears that each new family with OPCA differs from the previously published ones, it would seem to be useful to quanlify the clinical type with either a family name (ie Schut-Swier type) or a geographic name (ie Wyoming type; see Pouzcher and Barbeau, this issue), until a biochemical marker is found. This would avoid the essential difficulties inherent in the use of eponyms which give the impression that we are dealing with different diseases, when this is not always the case. It is possible that eventually all the "types" and "sub-types" will be recognized as the various phenotypes of a common genotype.

Other difficulties encountered in this field of research are the problems of quantification of symptoms and of the stage of the disease. Following the lead of De Falco et al (1979), Pourcher and Barbeau (this issue) presented a detailed scheme for quantification of most symptoms encountered in the various ataxic syndromes, as well as a new staging system similar to the one commonly used in Parkinson's disease. These authors field tested this new scheme on 47 ataxic patients and found it easy to use and reliable. It will now be proposed for possible adoption by the Research Committee on Hereditary Ataxia of the World Federation of Neurology.

Finally, the search for valid experimental models of ataxia in animals continues. As will be seen in this issue (De Michele et al), 3-acetyl pyridine injection is probably the easiest and most reproducible model to use because the amount of damage produced can be titrated and objectively measured (Jolicoeur et al, 1979). However two new models have recently been studied and may eventually be of use. The first one has received the unfortunate name of "Dystonia Musculorum Deformans" (Messer et al, 1980). This mouse neurological mutant shows pathological damage in many areas, but particularly in the dorsal root ganglia, the posterior columns, the red nucleus and the basal ganglia. It has not yet been systematically studied for its relationship to Friedreich's ataxia. The other model, resembling OPCA more closely, would appear to have been found in a mutant 
Gordon Setter dog (Troncoso et al, 1980).

\section{PATHOPHYSIOLOGY OF SYMPTOMS IN FRIEDREICH'S ATAXIA}

In the absence of a clear indication as to the causative factor in this disease, we must content ourselves with explaining the biochemical defects underlying the development of the main symptoms: diabetes, ataxia, a dying-back neuropathy, muscle weakness, scoliosis, and finally hypertrophic cardiomyopathy. Progress in our research during the last five years now permits the elaboration of a working model for such pathogenetic mechanism. This is illustrated in Figure 1 and is detailed below:
The centerpiece of our model is a proposition for the existence of an energy deprivation state in milochondria. Such a conclusion is derived from the observations of possible impairment in pyruvate dehydrogenase (PDH) activity (Blass et al, 1976), of acetyl $\mathrm{CoA}$ deficits leading to a defect in the synthesis of acetylcholine (Gibson et al, 1975), from the increased urinary loss of ornithine in these patients (Lemieux et al, 1976), a fact which may be coupled to a defect in mitochondrial oxidative phosphorylation (Stumpf and Parks, 1980), and from marked compensatory defects in the tissue dicarboxylic aminoacids, aspartic and glutamic acids (Robinson, 1968; Huxtable et al, 1979) in these patients. Such a proposed mitochon- drial energy defect would be both central (cerebellar vermis, Purkinje cells and dorsal root ganglia) and peripheral (sensory nerves at nodes of Ranvier; possibly some cranial nerves). It would be responsible secondarily for many of the observed symptoms in Friedreich's ataxia:

\section{(a) Muscle weakness}

Muscle weakness is present in the majority of Friedreich's patients after a few years (Geoffroy et al, 1976; Bertagnolio et al, this issue). It affects primarily the lower limbs and seems to be worse and more rapidly progressive in those patients who develop diabetes. In latter years the upper limbs become similarly affected. In the present issue, Richards and collaborators described

\section{PATHOGENESIS OF SYMPTOMS IN FRIEDREICH'S ATAXIA}

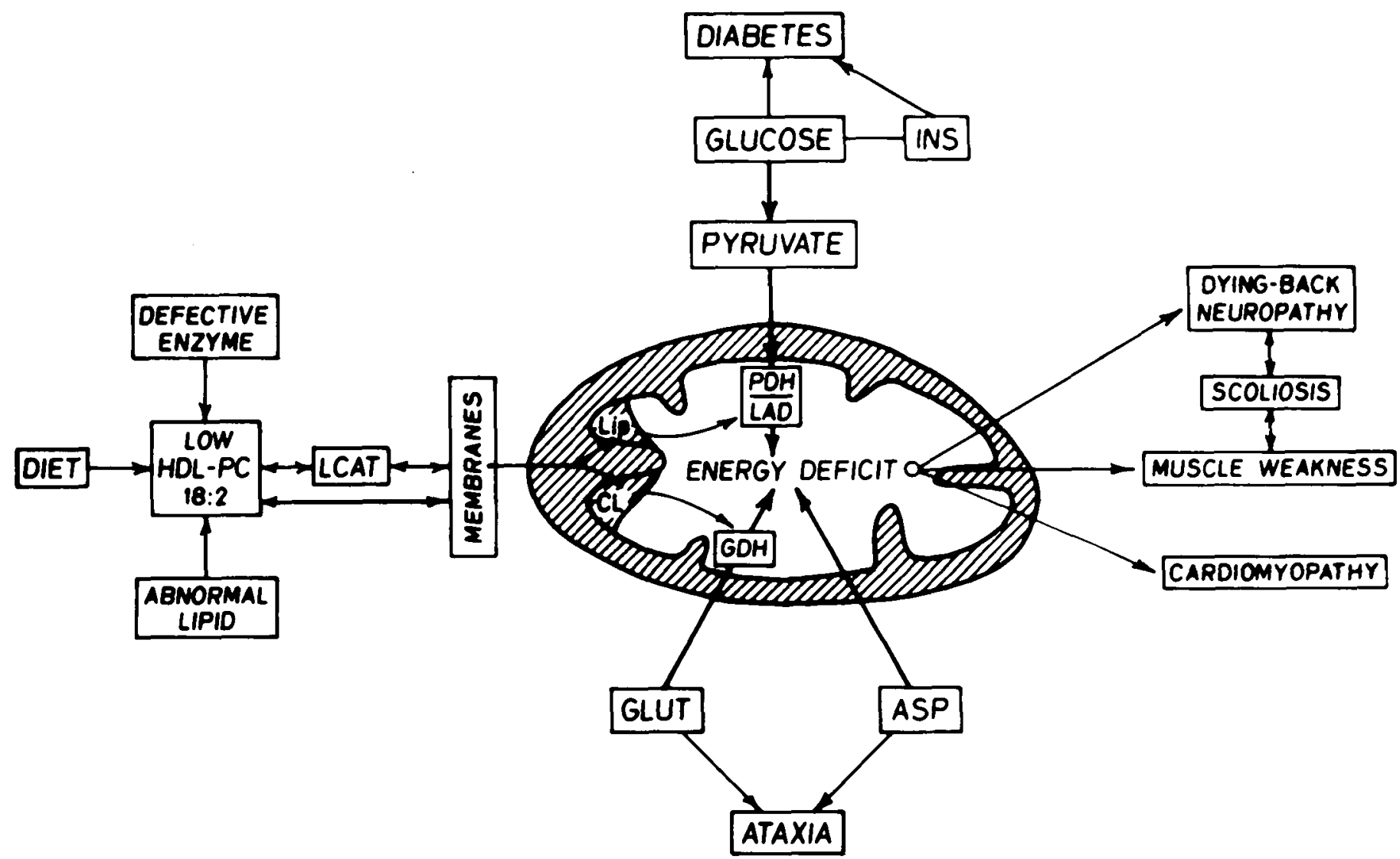

Figure $l$ - a scheme for the understanding of the pathogenesis of the symptoms of Friedreich's ataxia. Abbreviations used are: $H D L$ : high-density lipoproteins; $P C$ : phosphatidylcholine; 18:2: linoleic acid; $L C A T$ : Lecithin-cholesterol-acyl-transferase; Lip: Lipoic Acid; $C L$ : Cardiolipin; PDH: Pyruvate dehydrogenase; $L A D$ : Lipoamide dehydrogenase; $G D H$ : Glutamate dehydrogenase; $G L U T:$ Glutamic acid; $A S P$ : Aspartic acid; INS: insulin. 
a detailed and sensitive method to quantitate this muscle weakness in hereditary ataxia. It is easy to associate this muscle weakness to a mitochondrial energy defect, since the energy requirements of muscle are so high. Except for the reported PDH deficiency, no direct proof of this energy deficit has yet been obtained from the study of muscle, but such investigations are almost nonexistant.

\section{(b) Dying-back axonopathy (neuropathy)}

For many years it has been recognized that in Friedreich's ataxia the defect affects principally sensory fibers of large diameter in their axons rather than in the Schwann cells (Hughes et al, 1968; Peyronnard et al, 1976), as well as the large cells of the dorsal root ganglia. In the nerves, the observed changes are compatible with a socalled "dying-back phenomenon", as described by Cavanagh and others (Cavanagh, 1964; Schoental and Cavanagh, 1977; Prineas, 1969). The pathogenesis of this "dying-back" phenomenon (which implies that the damage is first evident at the distal end of the nerves and that it moves proximally) was initially attributed to an impairment in the anabolic machinery of the neuronal perikaryon (Cavanagh, 1964) resulting in decreased anoxal transport towards the periphery. In such a scheme the longest fibers would tend to be damaged first, and so would axons from bipolar cells like those of the dorsal root ganglia. However direct observation indicates that the larger fibers are involved before the longer ones. Thus, fiber diameter was found to be more important than axon length in determining the hierarchy of vulnerability, and it was shown that the disease process commences at the end of the broadest part of the nerve fiber (Veronesi et al, 1978). These observations, coupled with the knowledge of the peculiar energy demands of the node of Ranvier, led to the conclusion that energy deprivation within the axon might be especially critical at nodes of Ranvier, accounting for the observed changes in conduction velocity and the accumulation of transported material in adjacent regions. This led Spencer and collaborators (1979) to propose a new hypothesis for the pathogenesis of dying-back axonopathies, based on a postulated depletion of energy supplies in the axon and leading to a drop in the concentration of enzymes in distal regions particularly at the nodes of Ranvier, a local blockade of energydependent axonal transport and eventual distal nerve fiber degeneration. Such a finding is entirely compatible with our postulated mitochondrial energy depletion in Friedreich's ataxia.

\section{(c) Scoliosis}

The combination of muscle weakness and a peripheral neuropathy leads to the progressive development of a severe paralytic scoliosis (Geoffroy et al, 1976; Côté et al, 1979). This symptom has unfortunately been neglected by most physicians. Not only does it contribute to lung impairment and possibly to the cardiac hypertrophy, but it definitely makes it more difficult for the patient to enjoy life normally. It is thus with considerable welcome that we read of the important progress made in the use of specially designed molded wheel-chairs and early surgical correction of the scoliosis as reported in this issue by Allard and collaborators. These authors recommended orthopedic treatment for any scoliosis $20^{\circ}$ and over (bracing at $20^{\circ}$ and surgery over $40^{\circ}$ ). They also studied the pathomechanics of the relative rotation between the thoracic and lumbar segments which resulted in the almost sudden increase of Cobb measurements, particularly around the age of 10 .

\section{(d) Cardiomyopathy}

Previous papers in this series have clearly delineated the clinical (Côté et al, 1976a; Côté et al, 1979), electrical (Malo et al, 1976; Gattiker et al, 1976), hemodynamic (Côté et al, 1976b), pathological (Sanchez-Casis et al, 1976) and pharmacological (Huxtable, 1978) aspects of the cardiomyopathy. In the present issue, Pasternac and collaborators reviewed the findings in homozygotes, heterozygotes and carriers of the Friedreich's ataxia gene. They were able to show that most cases of Friedreich's ataxia had symmetric, concentric, hypertrophic cardiomyopathy while asymmetric septal hypertrophy, often obstructive, was probably a later stage of the disease. Lamarche et al (this issue) reviewed the findings of an histochemical study of three hearts from patients with that disease. Contrary to previous findings, the latter authors did not find increased calcium contents in the whole heart muscle, but found high concentrations of iron and of lipofuscin. Azari and collaborators (this issue) continued their fascinating study of the experimental cardiomyopathy of the hamster. They showed a marked increase in calcium concentration in the left ventricle after the development of the cardiomyopathy. Taurine given prophylactically clearly decreased the calcium accumulation and partially prevented the cardiac hypertrophy. Such observations lead to clinical trials with the calcium antagonist verapamil, and with taurine. In this respect it is important to recall the recent studies of Passantes-Morales and Gamboa (1980), and of Remtulla et al, (1979) concerning taurine, calcium transport and calcium fluxes in nerve terminals. These studies indicated that taurine produced a marked decrease in calcium accumulation in nerve endings in the chick retina and that, in a dose dependent manner, it had an inhibitory effect on both calcium uptake and release in synaptosomal preparations of rat brain. Finally, Rassin et al (1980) demonstrated a physiological relationship between taurine and glutamate during development, the synaptosomal pools of both amino-acids possibly being of importance in the regulation of one another (the relationship is actually an inverse one).

From the previously reported studies (Filla et al, 1978, 1979; Barbeau, 1979; Melançon et al, 1979), it was evident that, in Friedreich's ataxia, taurine uptake and kinetics were normal in most tissues (platelets, fibroblasts), but that taurine handling by the kidney was abnormal, ataxic patients excreting twice as much taurine from a taurine load as the control subjects. The most likely defects were either at the level of reuptake mechanisms in the proximal tubule, where the transport system for $\beta$-amino acids appears to be different from that found in other tissues (Melançon et al, this issue), or in an increased filtered load of 
$\beta$-amino acids from poor muscle reserve pools, without any alteration in the tubular reabsorption process. It is thus of interest that, in confirmation of previous observations (Barcelo, R., 1977, personal communication), renal defects could be observed in some cases of Friedreich's ataxia, often in conjunction with myoclonias (Kaplan et al, in press). This aspect of the problem merits further investigation, as does the possibility that an increased adrenergic tone may contribute to the cardiopathy and to increased taurine influx into cells. The sequence of morphological events in Friedreich's cardiomyopathy (Lamarche et al, this issue) could be the following: initial hypertrophy, degeneration of the cardiac muscle cell and necrosis associated with a non-specific inflammatory infiltrate and replacement fibrosis.

\section{(e) Ataxia}

Ataxia, or incoordination of gait and limb movements is, of course, the principal symptom of hereditary spinocerebellar degenerations. In these diseases it results from involvement of both the cerebellum (and its afferent and efferent systems) and the posterior columns. The pathology of Friedreich's has been clearly delineated (Hughes et al, 1968; Oppenheimer, 1979), but the biochemical anatomy is less clear. Robinson (1968) was the first to report a low concentration in the spinal cord of aspartic and glutamic acids, but this finding was thought to be non-specific because it was also found in motor neurone disease. Later, Perry et al (1978) reported low aspartic acid and glutamic acid in some cases of dominantly inherited cerebellar disorders of the olivo-ponto-cerebellar atrophy (OPCA) type (specifically the "Jackson-type" of OPCA). In 1979, Huxtable and collaborators found significantly lower concentrations of aspartic acid, glutamic acid and GABA in different parts of the cerebellum in two cases of Friedreich's ataxia. This was confirmed in a further two patients with another method of determination (Lemieux, B., unpublished results). This finding was not unexpected because similar results were also observed in many experimental models of ataxia, such as with 3-acetyl pyridine (Nadi et al, 1977; McBride et al, 1978; Butterworth et al, 1978), thiamine deficiency (Butterworth et al, 1979; Plaitakis et al, 1979) or even the "dystonia musculorum" mutant mouse (Messer and Gordon, 1979) or $\mathrm{x}$-irradiation (Rea et al, 1978). There is growing evidence that glutamate may be the neurotransmitter in the granule cells and parallel fibers of the cerebellum, while aspartate may be the neurotransmitter of climbing fibers. A decrease in the synaptic concentrations of these transmitters would be accompanied by cerebellar signs, such as ataxia. This has been found in the ataxia produced by 3-acetyl pyridine (Butterworth et al, 1978) and can easily be quantified with the battery of tests devised by Jolicoeur et al (1979). Using this model, De Michele et al (this issue) were able to show that the intraventricular injection of glutamate and/or aspartate could completely reverse the gait incoordination produced by 3-acetyl pyridine. This encouraging report was supported by studies (Butterworth et al, this issue) which indicated that feeding glutamine and/or asparagine was accompanied by a cerebellum and medulla increase in the precursor glutamine. The correction of gait ataxia by glutamate, and particularly aspartate, was a specific response not related only to the stimulants such as apomorphine, amphetamine or T.R.H. Only substance $P$ partially corrected gait ataxia. The fact that gait ataxia, accompanied by a cerebellar decrease content of aspartate and glutamate, can be reversed by the intraventricular injection of these amino acids, constitutes the strongest argument yet for the role of these substances in the production of the symptom ataxia. The recent identification of specific receptors to excitatory amino acids (the so-called N-methylD-aspartic acid, or "NMDA", receptors) and of a range of new antagonists, should shortly permit the development of analogs with similar action (Watkins, 1980).

Faced with the marked decrease in the cerebellum and spinal cord of aspartate and glutamate, one must ask whether the synthesis of these amino acids is impaired. To study this point, Barbeau et al (this issue) investigated glutamate dehydrogenase (GDH) ac- tivity in leukocytes of patients with Friedreich's ataxia and other forms of hereditary ataxia. They showed that there was a moderate $(20-40 \%)$, but significant decrease in activity, specifically in 22 patients with Friedreich's ataxia. The GDH levels in leukocytes were low normal in 9 patients with recessive spastic ataxia of CharlevoixSaguenay, normal in 6 of 8 patients with OPCA, and normal in 5 nonFriedreich recessive ataxias, compared to 44 normal age and sex-matched control subjects. However, the levels observed in Friedreich's ataxia and the overlap between results in patients and controls cannot reflect the primary defect (a 80 to $90 \%$ decrease would have been expected) and must signal either a secondary regulatory defect or a substrate deficit. Preliminary unpublished results using Mass-Spectrometry (Bertrand, M. et al) indicate that serum 2-oxoglutarate ( $\alpha$-Ketoglutarate) is within normal limits in these patients. Recently Plaitakis et al (1980) have found much more important decreases in the activity of GDH in some forms of OPCA. Our results (Barbeau et al, this issue) differ in OPCA, indicating that there may be different forms of the disease. The same authors (Plaitakis et al, 1980b), now report leukocyte GDH activity in 24 ataxic patients and 26 controls. GDH activity was significantly decreased $(30 \%$ to $50 \%$ of mean control activity) in leukocytes from 4 of the 6 sporadic and 5 of the 6 recessive adult cases. In all these patients, GDH activity was beneath the lowest control value. GDH activity in leukocytes from patients with juvenile-onset disease was within the control range. The authors draw the conclusion that a partial GDH deficiency correlates with adult onset recessive spino-cerebellar degeneration. This point requires confirmation from other laboratories. Another possibility that must be considered to explain the divergence between our results and those of Plaitakis is a methodological difference. This aspect of the problem will be developed further later-on in this review. Nevertheless, the significant loss of glutamate and aspartate, which is demonstrated in the above quoted studies, will eventually cause in more susceptible and vulnerable areas of the 
brain, such as the cerebellum, a deficit in these amino acids. Such a deficit, we have shown, can be accompanied by the symptom of ataxia, which can be corrected by the intraventricular substitution of the same substances, at least in the 3-acetylpyridine induced ataxia model (De Michele et al, this issue).

\section{(f) Diabetes and Pyruvate Metabolism}

The high prevalence of diabetes in Friedreich's ataxia has long been recognized and studied (Thoren, 1962; Joffe et al, 1968; Shapcott et al, 1976; Draper et al, 1979). In this issue, Tolis and collaborators confirm the presence of increased glucose tolerance in relatives and patients with Friedreich's ataxia, but report that, even if it appears to be slower, there is no quantitative defect in insulin release, nor in release of growth hormone or prolactin after a glucose load. Studies by Draper et al (1979) had shown that glycosylated hemoglobins are normal in Friedreich's ataxia, except in patients with overt clinical diabetes. Tolis et al (this issue), who confirm this latter point, thus conclude that the defect responsible for the diabetes is situated at the level of the entry of glucose into cells. A previous search for an explanation for this defect in glucose utilisation had shown that a glucose load was accompanied by an abnormal handling of pyruvate in the blood (Barbeau, 1975; Barbeau et al, 1976), illustrated by an increase in "abnormal Pyruvate Surface". This finding has been confirmed by many centers, and particularly in this issue by D'Angelo et al. It is thus important to pin-point the site of the block causing this generally agreed-to slowdown in pyruvate oxidation, but unfortunately there is still considerable controversy as to the direct involvement of pyruvate dehydrogenase (PDH) or of its components in this phenomenon. The first findings were reported by Kark et al (1974): these authors studied pyruvate oxidation in muscle in 7 patients with Friedreich's ataxia and 12 other types of ataxia, in addition to a number of neurological controls. Four of the 7 F.A. patients and 4 of the 12 "other ataxias", had low pyruvate oxidation in muscles. Blass and collaborators (1976) then studied this mechanism in cell cultures of 5 patients with F.A. (three of which were from the group previously reported to have impaired pyruvate oxidation in muscles). Disrupted fibroblasts from these patients were reported to oxidize both $1-14 \mathrm{C}$-Pyruvate (PDH activity) and ${ }^{1-14} \mathrm{C}$-ketoglutarate (KDGH activity) more slowly than did controls (43\% of $50 \%$ of control activity, respectively). Similarly, both activities were found low in the leukocytes of the only patient tested. Kark and Rodriguez-Budelli (1979) extended these studies by measuring the activities of $\mathrm{PDH}$ and $\mathrm{KGDH}$ in plateletenriched preparations from the blood of 14 patients with hereditary ataxias. Overall, low PDH activity was found in 6 of the 14 patients ( 2 of which also had low KGDH activity). PDHnormal and PDH-abnormal patients could not be distinguished by clinical criteria. Closer examination of the data, however, revealed that only 2 of the 7 Friedreich's ataxia tested had low platelet PDH activity. When the mean results of the 7 patients were calculated, the difference between that group and the control group was not significant. From their data, the above authors conceived the hypothesis of a genetic deficiency in the lipoamide dehydrogenase enzyme (LAD) common to the $\mathrm{PDH}$ and KGDH complexes as the possible defect in Friedreich's ataxia. Kark and his collaborators (RodriguezBudelli and Kark, 1978, 1979; Kark and Rodriguez-Budelli, 1979; Kark et al, 1980) presented kinetic evidence for such a LAD defect. Rodriguez-Budelli and Kark (1978) first studied 2 patients with Friedreich's ataxia, one previously reported by Blass et al, (1976) and the other the brother of another case also reported by Blass et al (1976). In both these patients, whose PDH and $\mathrm{KGDH}$ activities were low, lipoamide dehydrogenase (LAD) activity was found to be decreased in platelets (48$56 \%$ of normal) and in cultured fibroblasts from both families. Furthermore, the authors reported a defect in $\mathrm{Km}$ for lipoamide and in $\mathrm{Km}$ for NADH. They concluded that the data was consistent with a structural mutation of the gene coding for LAD. In later studies, the same authors (Rodriguez-Budelli and Kark, 1979) found these kinetic abnormalities in 5 of 11 patients with inherited ataxias and reported increased heat-lability of the platelet LAD in these 5 patients. Reduced activities of LAD relative to cytochrome oxidase in platelets has now been found (Kark and RodriguezBudelli, 1979) in 11 of their 17 patients with Friedreich's ataxia. It would appear that the deficient enzyme activity has been observed most often in a slowly progressive clinical subtype of the disease. Abnormal MichaelisMenten constants for LAD have now been found (Kark et al, 1980) in a total of six patients with low platelet enzyme activity, and in one case were discovered before the appearance of clinical symptoms. Values for platelet LAD activities in parents were claimed to be intermediate between controls and patients in these families (Kark et al, 1980).

The importance of these findings requires thorough examination and confirmation by many laboratories, since we may be discussing the enzyme defect in Friedreich's ataxia. We will examine in detail the results of these confirmatory experiments in other centers. First, it appears that only one other group has studied the oxidation of pyruvate or ketoglutarate in muscles of PA patients. Evans (1980) found no significant differences in muscle pyruvate oxidation in 9 spinocerebellar degeneration (SCD) patients compared with 33 non-SCD controls. When compared with control subjects who had histologically normal muscle, the SCD group showed a $33 \%$ reduction in total PDH complex activation; however this did not achieve statistical significance. Two SCD patients and 3 controls with histologically abnormal muscle showed deficient PDH complex activation. The author suggested, as we have (Barbeau, 1976), that these changes resulted from other biochemical abnormalities which secondarily alter PDH complex-regulation and pyruvate oxidation. Moreover the initial data (Kark et al, 1974) clearly indicates that this finding is not specific to Friedreich's ataxia. The results with fibroblasts were even more controversial. Barbeau et al (1976) studied oxidation of $1-14 \mathrm{C}$ pyruvate, $2-{ }^{14} \mathrm{C}$-pyruvate and $\mathrm{U}-{ }^{14} \mathrm{C}$ pyruvate in the fibroblasts of 8 patients with typical Friedreich's ataxia and found normal values. Stumpf and 
Parks (1979) studied PDH and KGDH activities in fibroblasts cultures from 10 Friedreich's ataxia patients and found normal values in all. Melançon et al (1979) in fibroblast cultures from 5 "typical" Friedreich's ataxia patients found normal values of PDH specific activity in early (7) passages but a nearly $50 \%$ reduction at later passages (14 to 21) in the ataxic patients, possibly indicating a greater fragility of the membranes in these subjects. Finally, Bertagnolio et al (this issue) were unable to find any reduction in pyruvate and palmitate oxidation or in carnitine-acyl-transferase activity in cultured fibroblast suspension from their patients, with or without stimulation by aspartate. However, they made the interesting observation that direct assay of the PDH complex is low in Friedreich's ataxia, but not if the cells are sonicated. We will return to this point later. The results in platelets are equally negative in most studies. Constantopoulos and collaborators (1979; personal communication to Dr. Blass) found no evidence for a PDH complex deficiency in platelets from two of the patients with Friedreich's ataxia in whom it was originally described. Filla et al (1978) found platelet PDH activity of 11 Friedreich's ataxia patients to be $84 \%$ of the control activity, but not significantly different from normal. Similarly platelet KGDH activity was $81 \%$ of the control activity, but again not significantly different. However it should be mentioned that 5/11 FA patients had values below the normal control range for both PDH and KGDH activity. Filla et al (this issue) have shown that the proportion of active PDH is not significantly different from normal in Friedreich's ataxia platelets. Stumpf and Parks (1978) also found no difference in the activity of the PDH complex (or of its $E_{1}$ and $E_{3}$ components) in platelets from 7 patients answering the strict criteria for "typical" Friedreich's ataxia. Only one study has attempted to verify the findings in leukocytes. Barbeau et al (1976) in 20 FA patients found no significant differences from 20 control leukocyte preparations.

The studies relating to the third component $\left(\mathrm{E}_{3}\right.$-LAD-lipoamide dehydrogenase) of the PDH complex (see
Ngo and Barbeau, 1978) are more difficult to analyse. In fibroblasts, normal activities were reported by Melançon et al (1978a; 1978b; 1979), Stumpf and Parks (1979) and D'Angelo et al (this issue). In platelets normal activities were observed by Filla et al (1978), Stumpf and Parks (1978). The kinetics ( $\mathrm{Km}$ and $\mathrm{Vmax}$ ) of LAD were studied, and found normal, in fibroblasts by Melançon et al (1978), Stumpf and Parks (1979) and Bertagnolio et al (this issue), and in platelets by Stumpf and Parks (1978). However, in serum, low activity values for LAD were found in a significant number of patients with Friedreich's but not in all (Barbeau et al, 1976, 1979; Filla et al, 1978; Melançon et al, 1978; D'Angelo et al, this issue, Melançon et al, this issue).

Many factors should be considered when trying to interpret these results: choice of patients and controls; statistical problems; cell preparation and assay conditions (Stumpf and Parks, 1979; Melançon et al, 1978b and Kark et al, 1979). All authors, except Kark and his collaborators, accept the strict clinical criteria for selection of Friedreich's ataxia patients defined by Geoffroy et al (1976). Kark and collaborators have included patients whom we would not call Friedreich's ataxia. These authors prefer to define a disease on the basis of biochemical data, rather than clinical presentation. Although we agree that this is correct when the primary gene product has been identified as a marker, until then this tends to confuse the issue and lead to the acceptance of more "diseases" than are warranted. When the biochemical results are analyzed for the group of typical patients "as a whole", heterogeneity in the results indicates rather that the biochemical finding may be secondary to the disease, or even unrelated. It is also important to have two control groups if possible: a normal group and a "neurological" (preferably "other ataxia") group. Failure to do so, or the exclusive use of "neurological" controls, may explain some of the discrepancies found in the literature. It is also unfortunately true that many technical differences exist between the published papers. Some of these may be of eventual significance. Thus, Barbeau (1979) has shown through mixing experiments at various concentrations that Friedreich's ataxia serum (but not platelets or fibroblasts) seems to lack a heat-labile substance necessary for normal LAD activity. This substance appears to be contained mainly within the high density lipoprotein (HDL) fraction of serum, or to interact with this fraction. Similar substrate-related differences are reported for Lecithin-cholesterol acyl transferase (LCAT) by Huang et al (this issue). We will hypothesize later that this factor may be related to linoleic acid and/or to lipoic acid. In this respect, it is interesting that Melançon et al (this issue) observed a correction of serum LAD abnormalities in patients receiving long-term oral Lecithin (Phosphatidylcholine), a therapeutic approach based on the preliminary reports of Barbeau (1978b, 1979). This change in serum LAD appeared to correlate mainly with improvement in muscle strength.

In conclusion, regarding glucose and pyruvate metabolism, we can summarize the current status of the problem, by stating that all the evidence indicates that in vivo oxidation of pyruvate is slow in Friedreich's ataxia but that this is not a specific finding (Williams, 1979). Attempts to localize this defect within the pyruvate dehydrogenase (PDH) complex have resulted in incriminating the third component $\left(E_{3}\right.$-LAD): lipoamide dehydrogenase, which, in vivo, does not appear to be activated by the proper amount of substrate. However, in vitro, whether in platelets, leukocytes or fibroblasts, both $\mathrm{PDH}$ and $\mathrm{KGDH}$ complexes and their LAD component, as well as the kinetics of these components, appear to be normal, in most laboratories, except when certain technical conditions of disruption or preparation of the cells are modified. These facts indicate that the primary genetic defect is not to be found in the PDH or KGDH complexes or in LAD per se but that, in Friedreich's ataxia, the smooth interaction between these components may be abnormally regulated, possibly even under genetic control, by a factor, or factors, operating in blood or cell membranes (or both). We are thus dealing with a regulation problem in the access of pyruvate to the intra-mitochondrial 
energy utilization system. This may be one of the important factors leading to mitochondrial energy deprivation in Friedreich's ataxia, but it does not appear to be the abnormal gene product in this disease.

One possible consequence of a slowdown in the production of Acetyl-coA through the PDH complex, is an impairment in the synthesis of acetylcholine (Gibson et al, 1975). There is no direct evidence yet obtained in Friedreich's ataxia patients that this is the case, but the possibility has inspired new therapeutic approaches (Barbeau, 1978b). Thus Kark et al (1977) used the centrally active cholinesterase inhibitor physostigmine in 12 patients with various SCD. Forty minutes after a single dose, the scores improved by $35.7 \pm 4.7$ percent (means \pm SEM). Eight patients were then studied over sequential 3-month periods by a randomized double-blind trial of physostigmine versus placebo. With physostigmine, scores were $33.9 \pm 8.3$ percent better than before treatment or with placebo. Perlman et al (1980) from the same group recently showed that sustained oral use of doses of 8 $\mathrm{mg} /$ day, improved signs by about $30 \%$ over 6 months in all 10 patients who were studied. Oral doses up to 24 $\mathrm{mg} /$ day over a 2-3 year trial were found to be useful in 7 of 11 patients. The direct precursor of acetylcholine, choline, has also been used with some success in ataxia of various origins (Legg, 1978; Barbeau, 1978b; Blattel, 1979; Livingstone and Mastaglia, 1979). However the bad body odour caused by the metabolites of choline, makes this an impractical treatment. Better results are obtained with phosphatidyl-choline (Lecithin), still another precursor which clearly increases brain and adrenal gland acetylcholine content (Hirsch and Wurtman, 1978). Initial observations by Barbeau (1978b, 1978b and unpublished results) indicated a clear, but moderate improvement of muscle strength and well-being in over 50 patients with various forms of hereditary ataxia and mainly a slowing down of the disease process. These results have been confirmed by many authors but not yet published (Campanella, G., personal communication; Di Donato, S., personal communication; Bouchard, J.P., personal communication; Melançon et al, this issue). Double-blind studies are now underway with objective measurement methods (Richards et al, this issue). Thus these preliminary results indicate that an acetylcholine deficit may indeed exist in Friedreich's ataxia and be partially corrected by acetylcholine precursors; these findings are compatible with the mitochondrial energy deprivation postulated in this disease. However, another explanation exists for the results with Lecithin (Barbeau, 1979b): this precursor may be supplying deficient membrane components, such as linoleic acid (see infra).

\section{SEARCH FOR A CAUSAL FACTOR}

As we demonstrated above, the evidence in favor of mitochondrial energy deprivation is strong and may explain the pathogenesis of most of the symptoms observed in Friedreich's ataxia. However, we have not been able to find a clear-cut enzymatic or metabolic block in afferent systems usually supplying the substrates for mitochondrial energy requirements. No change in lipid oxidation has yet been demonstrated or suspected in Friedreich's ataxia. The deficits observed in the PDH-LAD complex and in GDH activity are both only partial (range of decrease: $15-40 \%$ ) and most likely secondary to a regulatory problem, rather than a mutation in enzymes of glucose or amino-acid metabolism. Some interesting observations concerning methodological problems encountered in the course of GDH (Barbeau et al, this issue; Bertagnolio et al, this issue) and PDH (Barbeau, 1979; Rodriguez-Budelli and Kark, 1979; Melançon, 1978b; Kark et al, 1979) determinations support the previously expressed hypothesis (Barbeau, 1978) that a membrane defect may exist in Friedreich's ataxia, and that this defect may affect the mitochondrial membrane itself. For example (Barbeau et al, this issue), a significant deficit in leukocyte GDH activity in Friedreich's ataxia found when the cells were dissociated through sonication methods, disappeared when the same cells were dissociated with Triton X-100, a powerful detergent. This pointed to the mitochondrial membrane (since
GDH and PDH are intra-mitochondrial), and particularly to a lipid or fatty acid component of that membrane.

Previous studies from our group have also indicated that something could be wrong with the membranes in Friedreich's ataxia (Barbeau, 1978), but none of the evidence was, by itself, conclusive. Thus, Filla et al (1979) only noted a small increase in the degree of echinocyte formation upon varying the environment of the cells, but no significant change in the phospholipid pattern in platelets from patients with Friedreich's ataxia. Similarly, Draper et al, (1979) in red cell membranes found no significant difference in total phospholipids, cholesterol or proteins, but a slight shift in the distribution of phospholipid classes with a small increase in phosphatidyl inositol and phosphatidyl serine. Butterfield et al (1979) found no alteration in the physical state of membrane lipids, in morphology, or in the staining profile of erythrocytes in Friedreich's ataxia. An altered conformation and/or organization of proteins in erythrocyte membranes in this disorder was nevertheless suggested by spin labeling studies. However, the minor changes seen in this disease were not specific because they have also been observed in Alzheimer's disease, even if they differ from the findings in Huntington's chorea, and muscular dystrophy (Butterfield, personal communication). Steinberg et al (1979) found essentially no abnormalities in hemagglutination by lectins in Friedreich's ataxia red blood cells. Thus the modifications observed are compatible with a small change in a major component or an important change in a still undefined minor component of the membrane. Searching for this minor component, Wong and Barbeau (this issue) found normal protein bands on SDS-polyacrylamide gel electrophoresis of erythrocytes as well as normal protein kinase activity and normal phosphorylation rates of the principal proteins. However, Huang et al (this issue) were able to demonstrate in erythrocyte ghost membranes from Friedreich's ataxia patients a significant decrease in the linoleic acid (18:2) content of phosphatidylcholine, thus a localized type of defect compatible with the spin labelling findings. 
This abnormality in linoleic acid content in a specific membrane component of cells is extremely important, even if it turns out not to be specific, as we will now try to demonstrate. In a later paragraph we will consider the why of this decreased concentration of phosphatidylcholine linoleic acid, but we would like to examine first the metabolic consequences of this defect. As is obvious from the above reports, the overall structure and functions of cell membranes are not significantly modified by this abnormality, because the linoleic acid of phosphatidylcholine constitutes only a minor component of the cell membrane. A decrease in the polyunsaturated linoleic acid content, in a structural component of the membrane such as phosphatidylcholine, could lead to a slight decrease in its fluidity that only special conditions of physical stress would detect.

However cell membrane linoleic acid serves as a precursor to important metabolic co-factors and as a supply pool to the membranes of inner microorganelles such as the mitochondria. It is at this level that the consequences of such a deficit in cell membrane linoleic acid could be extremely important, even if not disease specific.

It is well known, of course, that linoleic acid, and arachidonic acid, are the precursors of the important metabolic regulators called prostaglandins, and it is probable that a decreased cell supply of linoleic acid would be reflected in the production of these substances and, consequently, in the regulation of cytoplasmic calcium concentration (Bergstrom and Samuelson, 1965). To date, no study of this problem has been carried out in Friedreich's ataxia.

A more esoteric, and unexpected, derivative of membrane linoleic acid, is lipoic acid. In a series of brilliant studies, Carreau and his collaborators (Carreau et al, 1975; 1977) injected linoleic acid uniformly labelled to sucking rats from mothers deprived in essential fatty acids and studied the metabolites produced. They were able to clearly identify by chromatography (silica gel and gas-liquid) and massspectrometry, the presence of significant amounts of lipoic acid. This compound, of course, is the essential co-factor for most of the oxidative decarboxylation processes of $\alpha$-ketoacids, particularly in the PDH and $\mathrm{KGDH}$ complexes. It is also present in high concentrations in the mitochondrial inner membrane (independently of the protein-bound lipoic acid moeties of the above noted complexes) where it or a metabolite plays a role in the terminal reactions of oxidative phosphorylation in conjunction with unsaturated fatty acids (Griffiths and Hyams, 1977; Griffiths et al, 1977). Lipoic acid is also said to stimulate the conversion of eicosatrienoic acid to prostaglandins (Marnett and Wilcox, 1977). It acts as a mobile component of mitochondrial inner membrane, being an energy-coupling factor linking the ATP synthase complex and the electron-transfer chain.

Finally, there is some evidence that lipoic acid participates in the regulation (inhibition) of glutamate dehydrogenase (GDH) (Yanagawa and Egami,
1975). Thus a defect in the synthesis, metabolism or regulation of inner mitochondrial membrane lipoic acid could well be responsible for the "regulatory" enzyme changes in PDH, $\mathrm{KGDH}$ and GDH (all mitochondrial enzymes) observed in Friedreich's ataxia, and occasionally in other forms of ataxia, and this could be tied to an abnormal supply of cell membrane linoleic acid, particularly in phosphatidylcholine moieties.

A third possibility exists for cell membrane linoleic acid to play a role in the mitochondrial energy deprivation in this, and other, diseases. In inner mitochondrial membranes, $90 \%$ of total lipids are phospholipids, the main phosphatides being cardiolipin (diphosphatidylglycerol) (Fig. 2), (Ioannou \& Golding, 1979), phosphatidylcholine and phosphatidyl ethanolamine (Comte et al 1971, 1976). The mitochondrial inner membrane fatty

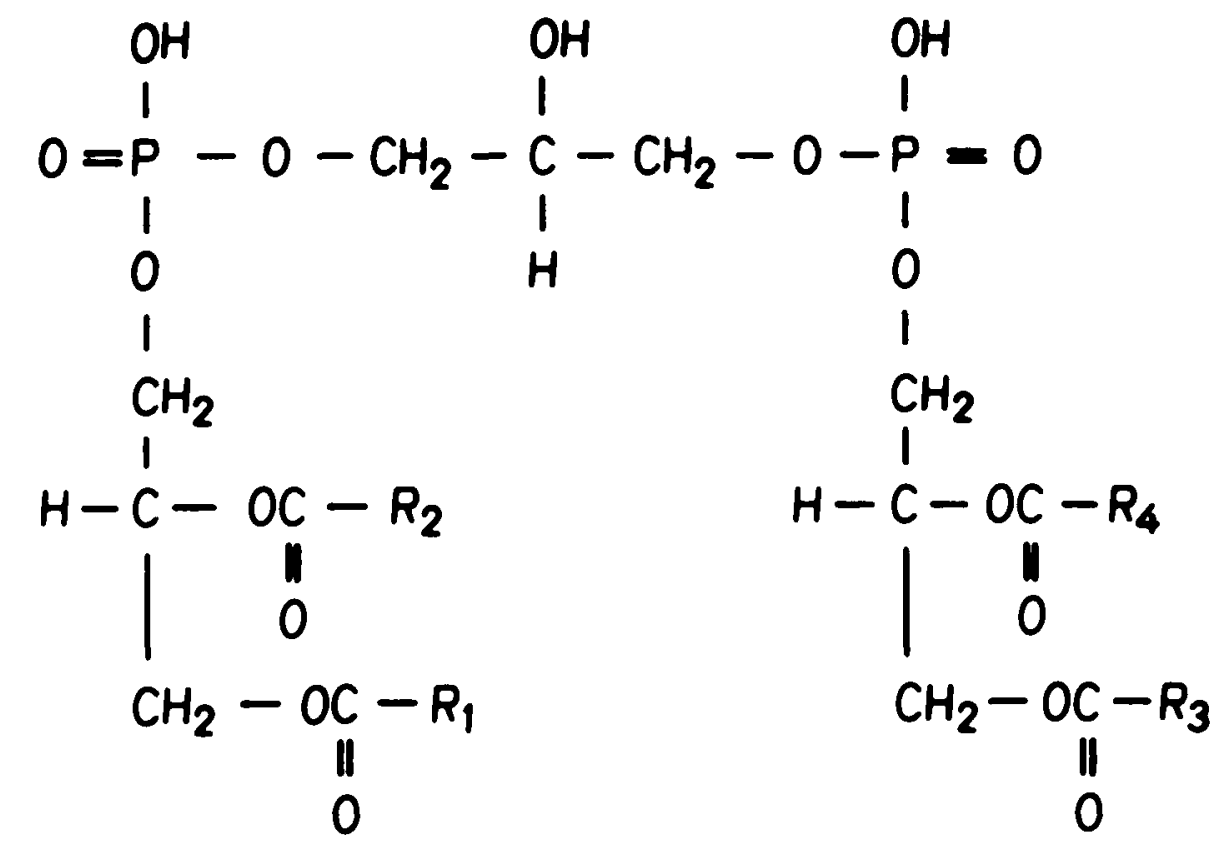

Figure 2 - structure of cardiolipin (diphosphatidyl glycerol). 
acids are mainly unsaturated, particularly cardiolipin. Thus, the concentration of linoleic acid $(18: 2)$ in phosphatidylcholine is $12.4 \%$, in phosphatidyl ethanolamine, $5.4 \%$ and in cardiolipin, $58.8 \%$. Biosynthesis of cardiolipin was found exclusively in the inner mitochondrial membrane (Davidson \& Stanacev, 1971; Hostetler \& Van den Bosch, 1972). It is noteworthy that this synthesis was strongly inhibited by nonionic detergents such as Triton $\mathrm{X}-100$. The turnover of fatty acids, and particularly of linoleic acid, in cardiolipin was very rapid (Landriscina et al, 1976), thus making this phospholipid susceptible to essential fatty acid deficiency. Any decrease in linoleic acid content of cardiolipin strongly influenced the physical properties of the mitochondrial inner membrane (Blomstrand and Svensson, 1974), with a concomitant loss of adenosine triphosphatase (Santiago et al, 1973) and mainly phosphorylative ability (Haslam, 1971). Nearly complete loss of oxidative phosphorylation and respiratory control occurred when the level of cellular unsaturated fatty acids fell below a certain minimum in yeast ( $20 \%$ of fatty acids unsaturated). It should be mentioned also that cardiolipin of the inner membrane had a strong regulatory (inhibitory) interaction with glutamate dehydrogenase (GDH) (Julliard and Gautheron, 1972; Godinot, 1973; Dodd, 1973). Finally it was noted that cardiolipin and phosphatidic acid were the most active ionophores among the phospholipids tested, with activities comparable to that of $\times 537 \mathrm{~A}$ in respect to the translocation of divalent cations (Tyson et al, 1976). Thus, it was evident that any change in the linoleic acid composition of inner membrane phospholipids, particularly cardiolipin, would have a profound effect on the Krebs cycle and oxidative phosphorylation. Because cardiolipin normally has, by far, the highest concentration of linoleic acid (50 to $80 \%$ depending on species and organ), this phospholipid should be profoundly affected by a low cellular pool of linoleic acid such as we find in Friedreich's ataxia. The metabolic consequences of this defect are catastrophic and have been described above. However, despite the fact that all these defects can occur in mammals, many of these intermediate steps have yet to be demonstrated in patients with Friedreich's ataxia.

The next important question is: what causes the decrease in the linoleic acid (18:2) content of cell membranes and cytoplasmic pools which may lead to similar decreases in the levels of prostaglandins and lipoic acid and in cardiolipin linoleic acid content, resulting in mitochondrial energy deprivation? Previous and current investigations from our Cooperative Study may give some clues. It is well known that the membrane composition of fatty acids, particularly the essential ones, is regulated by exchange with the exterior milieu, the lipoproteins, or directly with plasma (for a controversy on this subject see Field and Joyce, 1979; Seaman et al, 1979, 1980). Sixty percent of erythrocyte phosphatidylcholine is exchangeable (Reed, 1968), independently of the degree of saturation of their fatty acids (Renooij and Van Golde, 1977). Dietary fats are rapidly reflected on the fatty acid composition of human erythrocytes and chick cerebella (Horwitt et al, 1959). It is thus of interest that Huang et al (1978) reported no significant differences in the plasma fatty acid profile of the total lipid fraction, in the total cholesterol and phospholipid or in the percentage distribution of the individual phospholipid classes, but on the other hand they found major abnormalities in the composition of the high density lipoprotein (HDL) fraction. In Friedreich's patients, the relative proportion of HDL cholesterol and triglycerides was increased, while the relative protein content was greatly reduced and the proportion of phospholipids was normal. The apoprotein composition of HDL, however, appeared to be normal. LDL levels were slightly decreased. In further studies (Davignon et al, 1979), it was found that the fatty acid profile of cholesteryl-ester (CE) fractions was markedly deficient in linoleic acid (18:2) in both plasma and HDL. There was a compensatory increase in saturated acids. The HDL phospholipid fraction also showed a reduction in the proportion of $18: 2$ with a concomitant increase in stearic (18:0) and oleic acid (18:1), while the HDL triglyceride fraction showed only an increase in palmitoleic (16:1) and oleic acids. Although the total plasma CE fatty acid profile was perturbed in Friedreich's ataxia, total plasma phospholipid and triglyceride fatty acid patterns were unaffected. Further studies (Huang et al, this issue) indicated that the enzyme most involved in transfer of cholesterol from the membrane, Lecithin-cholesterol acyltransferase (LCAT), was reduced in Friedreich's ataxia, confirming the results of Yao et al (1976, 1978) on a smaller group of patients. Mixing experiments indicated that this LCAT deficit was secondary since it was corrected by a normal phosphatidylcholine substrate. Finally Huang et al (this issue) showed that red blood cell membranes were deficient in the 18:2 (linoleic acid) composition of their phosphatidylcholine, a most important point as seen previously. The authors postulated a metabolic defect in the incorporation of 18:2 into chylomicron phospholipids within the intestinal mucosa. These important findings must, however, be confirmed by other laboratories. Yao and Dyck (1978) found that 9 patients with Friedreich's ataxia and 39 with other neuropathies showed decreased linoleic acid in the phosphatidylcholine and lysophosphatidylcholine fractions of serum phospholipids compared with 73 healthy subjects. Obviously, these findings were not specific to Friedreich's ataxia, but may nevertheless reflect a reduced linoleate pool in this disease. Recently Walker et al (1980a, 1980b), using different methods of determination than the ones employed by Huang and collaborators, could not confirm the abnormalities in HDL previously reported. In particular the fatty acid profiles of total HDL and of the cholesterol esters of HDL and LDL were not found to be different from normal in 10 patients with Friedreich's ataxia. No good reasons, except methodological differences, explain this discrepancy. It is unlikely that the linoleic acid deficit is only present in French Canadian patients as suggested by Walker et al (1980b).

Assuming that further studies elsewhere confirm the results already observed by our group in more than 40 Friedreich's ataxia patients, one must ask how this deficit in HDL and 
membrane linoleic acid content could occur. As we have seen, Davignon et al (1979) postulated a defect in intestinal incorporation at the level of chylomicrons, but other possibilities must be considered. A diet low in essential fatty acids could produce similar results, but no evidence for such a deficient diet has yet been produced in these diseases. Similarly, a specific defect in one of the synthesizing enzymes may exist and give the above results. However, many of our findings were non specific and can be observed in a number of other neuropathies or hereditary ataxias. This would seem to militate against a disease specific process limited to Friedreich's ataxia. One last possibility must be seriously considered because, at this writing, it would best explain the findings: the decreased linoleic acid content in HDL and membranes could be due to a block in the incorporation, interference or competition for the normal substrate by some abnormal lipid or fatty acid in increased quantity. There are precedents for this possibility: in adrenomyeloneuropathy (the adult form of X-linked adrenoleucodystrophy with spastic paraparesis and chronic adrenal insufficiency), an excess of very long chain fatty acids $\left(\mathrm{C}_{26}\right.$ fatty acids) was demonstrated with markedly abnormal $C_{26} / C_{22}$ ratio (Igarashi et al, 1976; O'Neill et al, 1980). In that disease, Chazot et al (1979) showed low serum linoleic acid and increase in the saturated/unsaturated ratio for fatty acids. In Refsum's disease where phytanic acid (a 20 carbon methylated fatty acid) is accumulated, low serum and red cell linoleic acid contents have also been observed. Finally in Batten's disease (infantile form of neuronal lipofuscinosis) one finds in erythrocytes a decreased glutathione peroxidase activity associated with particularly low concentrations of linoleic acid in serum (Shukla et al, 1978). In Friedreich's ataxia no abnormal peaks have yet been observed in serum or tissue fatty acid analysis of extracts by gas-liquid chromatography (Huang et al, 1978; Walker et al, 1980a), but it should be mentioned that the range of fatty acids studied by usual methods is from 14:0 (Myristic acid) to $\mathrm{C}_{22}$ Pentaene. No data is available on short chain fatty acids, but this point is being looked at by our group (Bertrand et al, in preparation). It is of interest, in this respect, to recall that lipoic acid is a $\mathrm{C}_{8}$ compound with two SH-groups.

\section{CONCLUSION}

Thus, the pathophysiology of most symptoms in Friedreich's ataxia and possibly in many other forms of hereditary ataxia could be explained by the following scheme (Fig. 1):

The primary factor appears to be interference with the incorporation of linoleic acid to the phosphatidylcholine component of high density lipoproteins, and consequently of cell membranes. This could, in some cases, be the result of dietary changes; in other instances a block at the level of intestinal absorption (genetic or not) could be postulated; finally in a certain number of diseases, the presence in increased quantities of abnormal lipids or fatty acids would competitively impair that incorporation of the essential fatty acid, linoleic acid. Which of these mechanisms is active in Friedreich's ataxia is unknown. Abnormal concentrations of phosphatidylcholine linoleic acid (18:2) in cell membranes and cytoplasmic pools would result in alterations in the fatty acid composition of cardiolipin in the inner membrane of mitochondria, with important metabolic consequences upon energy production by the tricarboxylic acid (TCA) cycle and eventual mitochondrial energy deprivation. In parallel, a modification of prostaglandin synthesis, and of lipoic acid availability, because of a deficit in the precursor linoleic acid, would further impair the normal functioning of the Krebs cycle, particularly at the level of the oxidation of $\alpha$-ketoacids. All these factors contribute in variable ways to the mitochondrial energy deprivation which, in turn, can be held directly responsible for such cardinal symptoms as muscle weakness, dyingback neuropathy, scoliosis and the hypertrophic cardiomyopathy. The regulatory defect produced at the level of the pyruvate dehydrogenase complex (as a result of the impaired availability of lipoic acid, for example), is translated in one direction into a slow-down in the catabolism of pyruvate towards acetyl-CoA, acetylcholine and the Krebs Cycle, and in the other direction into a limitation of glucose entry into cells favoring the development of chemical then clinical diabetes. It is not impossible that this trait (diabetes, slow pyruvate utilization) be due to a different (but closely linked) recessive gene from that of Friedreich's ataxia. Consequent to this deficient phosphorylation, there is a deficit in the concentrations of glutamic and aspartic acids. This tissue deficit in important excitatory neurotransmitters in certain more metabolically vulnerable areas such as the cerebellum, brain stem and dorsal root ganglia (more vulnerable because they are areas of intense metabolic activity or because they function already at threshold), would be directly responsible for the symptom "ataxia". Evidence for this is obtained from experiments reported in this issue (De Michele et al) indicating that the symptom of gait incoordination produced by injections of 3-acetylpyridine and accompanied by low cerebellar concentrations of aspartic acid and glutamic acid, can be completely reversed by the intraventricular injection of glutamate or, even more so, of aspartate.

It is thus evident that this scheme (or parts thereof) may explain the symptoms of a great number of diseases in the field of hereditary ataxias. Individual entities would involve a specific enzyme defect (genetically determined or secondarily induced) at one of the crucial crossroads of this scheme. Depending on how far away from the central core defect (mitochondrial energy production), or on how localized to certain tissues (for example node of Ranvier versus dorsal root ganglia) that enzymatic block is situated, the whole rainbow of phenotypic expressions could be produced individually or in association. At the present time, this scheme is compatible with everything we know of the biochemistry of any of the hereditary spinocerebellar degenerations. For Friedreich's ataxia particularly, and contrary to previously expressed opinions in the literature, we do not think the primary gene involves the enzymatic complexes of PDH, $\mathrm{KGDH}$ or GDH, but rather that it is the consequence of interference with 
the incorporation of linoleic acid to phosphatidylcholine moieties of lipoproteins and/or cell membranes.

\section{ACK NOWLEDGEMENTS}

The studies from the authors' laboratory reported in this paper were supported by grants from L'Association Canadienne de l'Ataxie de Friedreich and the Department of National Health and Welfare. Ottawa. The cost of hospitalisation in the metabolic units was graciously borne by the Federal and Quebec Provincial Governments. The author would like to thank particularly Miss Diane Magnan and Miss Suzanne Gariepy who acted as coordinating secretaries during the studies of Phase Three.

\section{REFERENCES}

BARBEAU, A. (1975). Preliminary studies on pyruvate metabolism in Friedreich's ataxia. Trans. Am. Neurol. Assoc. 100, 164-165.

BARBEAU, A. (1976). Friedreich's Ataxia 1976 - An Overview. Can. J. Neurol. Sci. 3. 389397.

BARBEAU, A. (1978a). Friedreich's Ataxia 1978 - - An Overview. Can. J. Neurol. Sci. 5. 161-165.

BARBEAU, A. (1978b). Emerging treatments: Replacement therapy with choline or lecithin in neurological diseases. Can. J. Neurol. Sci. 5. $157 \cdot 160$.

BARBEAU, A. (1978c). Lecithin in neurological diseases. New Engl. J. Med. 299, 200-201.

BARBEAU, A. (1979). Friedreich's Ataxia 1979 - An Overview. Can. J. Neurol. Sci, 6, 311319.

BARBEAU, A. (1980). Distribution of Ataxia in Quebec. In: Spinocerebellar Degenerations. Ed., I. Sobue, Univ. Tokyo Press, pp. 121141.

BARBEAU, A., BUTTERWORTH, R.F., NGO. T. BRETON, G., MELANCON, S., SHAPCOTT, D., GEOFFROY, G. and LEMIEUX, B. (1976). Pyruvate metabolism in Friedreich's Ataxia. Can. J. Neurol. Sci. 3, 379-388.

BERGSTROM, S. and SAMUELSON, B. (1965). Prostaglandins. Ann. Rev. Biochem. 34, $10 !-108$.

BLASS, J.P. (1979). Disorders of pyruvate metabolism. Neurology 29, 280-286.

BLASS, J.P., KARK, R.A.P. and MENON, N.K. (1976). Low activities of the pyruvate and oxoglutarate dehydrogenase complexes in five patients with Friedreich's ataxia. New Engl. J. Med. 295, 62-67.

BLATTEL. R.A. (1979). Use of choline in the treatment of ataxia associated with multiple sclerosis. Can. Med. Ass. J. 121, 1568.

BLOMSTRAND, $R$, and SVENSSON, $L$. (1974). Studies on phospholipids with particular reference to cardiolipin of rat heart after feeding Rapeseed oil. Lipids 9, 771-779.

BOUCHARD, J.P., BARBEAU, A., BOUCHARD, R. and BOUCHARD, R.W.
(1978). Autosomal Recessive Spastic Ataxia of Charlevoix-Saguenay. Can. J. Neurol. Sci. 5. 61-69.

BUTTERFIELD, D.A., LEUNG, P.K., MARKESBERY, W.R. and BARBEAU, A. (1979). Evidence for an altered physical state of membrane proteins in erythrocytes in Friedreich's Ataxia. Can. J. Neurol. Sci. 6. 295-298.

BUTTER WORTH, R.F., HAMEL, E., LANDREVILLE, F. and BARBEAU, A. (1978). Cerebellar ataxia produced by 3-acetyl pyridine in rat. Can. J. Neurol. Sci. 5. 131-133.

BUTTER WORTH, R.F., HAMEL, E., LANDREVILLE, F. and BARBEAU, A. (1979). Amino acid changes in thiaminedeficient encephalopathy: some implications for the pathogenesis of Friedreich's Ataxia. Can. J. Neurol. Sci. 6, 217-222.

CARREAU. J.P.. LAPOUS. D. and POULIN, J. (1975). Un dérivé vraisemblablement essentiel de l'acide linoléique: l'acide lipoïque, coenzyme universel de l'oxydation des acides cétoniques. C.R. Acad. Sc. Paris 281, 941944.

CARREAU, J.P., LAPOUS, D. and POULIN, J. (1977). Signification des acides gras essentiels dans le métabolisme intermédiaire. Hypothèses sur la synthèse de l'acide lipoïque. Biochimie 59, 487-496.

CAVANAGH, J.B. (1964). The significance of the "dying-back" process in experimental and human neurological disease. Int. Rev. Exp. Pathol. 3, 219-267.

CHAZOT, G., SASSOLAS, G., KOPP, N., TRILLET, $M$. and SCHOTT, B. (1979). Adrénomyéloneuropathie: forme adulte d'adrénoleucodystrophie - Paraparésie spastique et insuffisance surrénale chronique - a propos de 3 cas. Rev. Neurol. (Paris) 135. 211-220.

COMTE, J., GAUTHERON, D., PEYROUX, F. and MICHEL, G. (1971). Lipid composition and endogenous respiration of pig heart mitochondria. Lipids $6,882-888$.

COMTE, J., MAISTERRENA, B. and GAUTHERON, D.C. (1976). Lipid composition and protein profiles of outer and inner membranes from pig heart mitochondria - comparison with microsomes. Biochim. Biophys. Acta 419, 271-284.

COTE, M., BUREAU, M., LEGER, C., MARTIN, J., GATTIKER, H., CIMON, $M$. LAROSE, $A$, and LEMIEUX, B. (1979). Evolution of cardiopulmonary involvement in Friedreich's Ataxia. Can. J. Neurol. Sci. 6, 151-157.

COTE, M., DAVIGNON, A., ELIAS, G., SOLIGNAC, A., GEOFFROY, G., LEMIEUX, B. and BARBEAU, A. (1976a). Hemodynamic findings in Friedreich's Ataxia. Can. J. Neurol. Sci. 3, 333-336.

COTE, M., DAVIGNON, A., PECKO-DROUIN, K., SOLIGNAC, A., GEOFFROY, G., LEMIEUX, B. and BARBEAU, A. (1976b). Cardiological signs and symptoms in Friedreich's Ataxia. Can. J. Neurol. Sci. 3, 319-321.

DAVIDSON, J.B. and STANACEV, N.Z.
(1971). Biosynthesis of cardiolipin in mitochondria isolated from guinea pig liver. Biochem. Biophys. Res. Comm. 42, 11911199.

DAVIGNON, J., HUANG, Y.S., WOLF, J.P. and BARBEAU, A. (1979). Fatty acid profile of major lipid classes in plasma lipoproteins of patients with Friedreich's ataxia - Demonstration of a low linoleic acid content most evident in the cholesterolEster fraction. Can. J. Neurol. Sci. 6, 275283.

DE FALCO, F.A., MANSI, D., VENTOLA, F., FILlA, A. and CAMPANELlA, G. (1979). Proposta di une scheda di relevamento clinico delle eredoatassie spinocerebellari. Acta Neurol, Quaderno 39, 103109.

DODD, G.H. (1973). The interaction of glutamate dehydrogenase and Malate dehydrogenase with phospholipid membranes. Eur. J. Biochem. 33, 418-427.

DRAPER, P., HUANG, Y.S., SHAPCOTT, D., LEMIEUX, B., BRENNAN, M., BARBEAU, A. and DAVIGNON, J. (1979a). Erythrocyte membrane lipids in Friedreich's Ataxia. Can. J. Neurol. Sci, 6, 291-294.

DRAPER, R., SHAPCOTT, D., LAROSE, A., STANKOVA, J., LEVESQUE, F. and LEMIEUX, B. (1979b). Glucose Tolerance and Erythrocyte insulin receptors in Friedreich's Ataxia. Can. J. Neurol. Sci. 6. 233-239.

EVANS, O.B. (1980). Muscle Pyruvate Oxidation in Spinocerebellar Degenerations. Ann. Neurol. 8, 129.

FIELD. E.J. and JOYCE, G. (1979). Origin of red-cell membrane differences in multiple sclerosis. Lancet 2, 1012-1013.

FILLA, A., BUTTERWORTH, R.F. and BARBEAU, A. (1979). Pilot studies on membranes and some transport mechanisms in Friedreich's Ataxia. Can. J. Neurol. Sci. 6, 285-289.

FILLA, A., BUTTER WORTH, R.F.. GEOFFROY, G., LEMIEUX. B. and BARBEAU, A. (1978). Serum and platelet lipoamide dehydrogenase in Friedreich's Ataxia. Can. J. Neurol. Sci. 5, 111-114.

GATTIKER, H.F., DAVIGNON, A., BOZIO, A., BATLLE-DIAZ, J., GEOFFROY, G., LEMIEUX, B. and BARBEAU. A. (1976). Echocardiographic findings in Friedreich's Ataxia. Can. J. Neurol. Sci. 3, 329-332.

GEOFFROY, G., BARBEAU, A., BRETON, G., LEMIEUX, B., AUBE, M., LEGER, C. and BOUCHARD, J.B. (1976). Clinical description and roentgenologic evaluation of patients with Friedreich's Ataxia. Can. J. Neurol. Sci. 3, 279-286.

GIBSON, G.E., JOPE, R. and BLASS, J.P. (1975). Decreased synthesis of acetyl-choline accompanying impaired oxidation of pyruvic acid in rat brain minces. Biochem. J. 148, 17 23.

GODINOT, C. (1973). Nature and possible functions of association between glutamate dehydrogenase and cardiolipin. Biochemistry $12,4029-4034$. 
GRIFFITHS, D.E. and HYAMS, R.L. (1977) Oxidative phosphorylation: A role for lipoic acid and unsaturated fatty acids. Biochem. Soc. Trans. 5, 207-208.

GRIFFITHS, D.E., CAIN, K. and HYAMS, R.L. (1977). Oxidative phosphorylation: A new biological function for lipoic acid. Biochem. Soc. Trans. 5, 205-207.

HASLAM, J.M. (1971). The effects of depletion of unsaturated fatty acids on the energydependent reactions of least mitochondria. Biochem. J. 123, 6p-7p.

HIRSCH, M.J. and WURTMAN, R.J. (1978) Lecithin consumption increases acetylcholine concentrations in rat brain and adrenol gland. Science 202, 223-225.

HORWITT, M.K., HARVEY, C.C. and CENTURY. B. (1959). Effect of Dietary fats on fatty acid composition of human erythrocytes and chick cerebella. Science $131,917-918$

HOSTETLER, K.Y. and VAN den BOSCH, $\mathrm{H}$. (1972). Subcellular and submitochondrial localization of the biosynthesis of cardiolipin and related phospholipids in rat liver. Biochim. Biophys. Acta 260, 380-386.

HUANG, Y.S., NESTRUCK, A.C., BARBEAU, A., BOUCHARD, J.P. and DAVIGNON, J. (1978). Plasma lipids and lipoproteins in Friedreich's Ataxia and familial spastic ataxia - Evidence for an abnormal composition of high density lipoproteins. Can. J. Neurol. Sci. 5, 149-156.

HUGHES, T.J., BROWNELL, B. and HEWER, R.L. (1968). The peripheral sensory pathway in Friedreich's Ataxia. An examination by light and electron-microscopy of the posterior nerve roots, sensory nerves in cases of Friedreich's Ataxia. Brain 91, 803-818.

HUXTABLE, R.J. (1978). Cardiac Pharmacology and cardiomyopathy in Friedreich's Ataxia. Can. J. Neurol. Sci. 5, 83-91.

HUXTABLE, R.J., AZARI, J., REISINE, T., JOHNSON, P., YAMAMURA, H.I, and BARBEAU, A. (1979). Regional distribution of Amino acids in Friedreich's Ataxia brains. Can. J. Neurol. Sci, 6, 255-258.

IGARASHI, M., SCHLAUMBERG, H.H., POWERS, J., KISHIMOTO, Y., KOLONDY, E. and SUZUKI, K. (1976). Fatty acid abnormality in adrenoleukodystrophy. $J$. Neurochem. 26, 851-860.

IOANNOU, P.V. and GOLDING, B.T. (1979). Cardiolipins: their chemistry and biochemistry. Progr. Lipid Res. 17, 279-318.

JOFFE, B.I., SEGAL, 1 . and COOPER, W. (1968). Evolution of diabetes mellitus in cases of Friedreich's Ataxia. J. Neurol. Neurosurg. and Psychiat. 36, 484-493.

JOLICOEUR, F.B., RONDEAU, D.B., HAMEL, E., BUTTER WORTH, R.F. and BARBEAU, A. (1979). Measurement of ataxia and related neurological signs in the laboratory rat. Can. J. Neurol. Sci. 6, 209215.

JULLIARD, J. and GAUTHERON, D.C. (1972). Regulatory effects of mitochondrial lipids on glutamate dehydrogenase NAD(P). FEBS Letters 25, 343-345.
KARK, R.A.P., BLASS, J.P. and ENGEL, W.K. (1974). Pyruvate oxidation in neuromuscular diseases - Evidence for a genetic defect in two families with the clinical syndrome of Friedreich's Ataxia. Neurology 24, 964-971.

KARK, R.A.P., BLASS, J.P, and SPENCE, M.A. (1977). Physostigmine in familial ataxias. Neurology 27, 70-72.

KARK, R.A.P. and RODRIGUEZ-BUDELLI, M. (1979a). Pyruvate dehydrogenase deficiency in spinocerebellar degenerations. Neurology 29, 126-131.

KARK, R.A.P. and RODRIGUEZ-BUDELLI, M.M. (1979b). Clinical correlations of partial deficiency of lipoamide dehydrogenase. Neurology 29, 1006-1013.

KARK, P.. RODRIGUEZ-BUDELLI, $M$. and BECKER, D.M. (1979). Methodology in evaluating pyruvate oxidation. Ann. Neurol. 5, 595-596.

KARK, R.A.P., RODRIGUEZ-BUDELLI, M., PERLMAN, S., GUELLEY, W.F. and TOROK. K. (1980). Preclinical diagnosis and carrier detection in ataxia associated with abnormalities of lipoamide dehydrogenase. Neurology 30, 502-508.

LANDRISCINA, C., MEGLI, F.M. and QUAGLIARIELLO, E. (1976). Turnover of fatty acids in rat liver cardiolipin: comparison with other mitochondrial phospholipids. Lipids 11, 61-65

LEGG, N.J. (1978). Oral choline in cerebellar ataxia. Brit. Med. J. 2, 1403-1404.

LEMIEUX, B., BARBEAU, A., BERONIADE, V., SHAPCOTT, D., BRETON, G., GEOFFROY, G. and MELANÇON, S. (1976). Amino acid metabolism in Friedreich's Ataxia. Can. J. Neurol. Sci. 3, 373-378.

LIVINGSTONE, I.B. and MASTAGLIA, F.L. (1979). Choline chloride in the treatment of ataxia. Brit. Med. J. 2, 939.

MALO, S., LATOUR, Y., COTE, M., GEOFFROY, G., LEMIEUX, B. and BARBEAU, A. (1976). Electrocardiographic and vectocardiographic findings in Friedreich's Ataxia. Can. J. Neurol. Sci. 3, 323-328.

MARNETT, L.J. and WILCOX, C.L. (1977). Stimulation of prostaglandin biosynthesis by lipoic acid. Biochim. Biophys. Acta 487, 222-230.

McBRIDE, N.J., REA, M.A. and NADI, N.S. (1978). Effects of 3-acetylpyridine on the levels of several amino-acids in different CNS regions of the rat. Neurochemical Research 3, 793-801.

MESSER, A. and GORDON, D. (1979). Changes in whole tissue biosynthesis of $\gamma$ aminobutyric acid (GABA) in basal ganglia of the dystonia $\left(\mathrm{dt}^{\mathrm{atb}}\right)$ mouse. Life Sci. 25 , 2217-2221.

MESSER, A. and STROMINGER, N.L. (1980). An allele of the mouse Mutant dystonia musculorum exhibits lesions in red nucleus and striatum. Neuroscience 5,543 549.

MELANCON, S.B., POTIER, M., DALLAIRE, L., FONTAINE, G., GRENIER, B., LEMIEUX, B., GEOFFROY, G. and
BARBEAU, A. (1978a). Lipoamide dehydrogenase in Friedreich's Ataxia fibroblasts. Can. J. Neurol. Sci. 5, 115-118.

MELANCON, S.B., DALLAIRE, L. and POTIER, M. (1978b). Lipoamide dehydrogenase in cultured human skin fibroblasts. Clin. Chimica Acta 87, 29-34.

MELANÇON, S.B., POTIER, M., DALLAIRE, L., ROLLIN, P., FONTAINE, G, and GRENIER, B. (1979). Pyruvate dehydrogenage, lipoamide dehydrogenase and citrate synthase activity in fibroblasts from patients with Friedreich's and Charlevoix-Saguenay Ataxia. Can. J. Neurol. Sci. 6, 241-242.

NADI, N.S., KANTER, D., McBRIDE, W.J. and APRISON, M.H. (1977). Effects of 3-acetylpyridine on several putative neurotransmitter amino acids in the cerebellum and medulla of the rat. J. Neurochem. 28 . 661-662.

NGO, T.T. and BARBEAU, A. (1978). Lipoa mide dehydrogenase regulation in rat brain. Can. J. Neurol. Sci. 5, 105-109.

O'NEILL, B.P., MOSER, H.W. and MARMION, L.C. (1980). The adrenoleukomyeloneuropathy (ALMN) complex: Elevated $C_{26}$ Fatty acid in cultured skin fibroblasts and correlation with disease expression in three generations of a kindred. Neurology 30.352 .

OPPENHEIMER, D.R. (1979). Brain lesions in Friedreich's Ataxia. Can. J. Neurol. Sci. 6. 173-176.

PASANTES-MORALES. $H$. and GAMBOA. A. (1980). Taurine effects on calcium transport in synaptosomes. Am. Soc. Neurochem. Proc. 11, 193.

PERLMAN, S.L., KARK, R.A.P. SCHLECTER, B., BUDELLI, M.R. and YOUKELES, L. (1980). Preliminary studies of oral physostigmine in the long-term management of Inherited ataxias. Neurology $30,381-382$

PERRY, T.L., HANSEN, S., CURRIER, R.D. and BERRY, K. (1978). Abnormalities in neurotransmitter amino acids in dominantly inherited cerebellar disorders. Adv. Neurol. $21,303-314$

PEYRONNARD, J.M., LAPOINTE, L., BOUCHARD, J.P., LAMONTAGNE. A. LEMIEUX. B. and BARBEAU, A. (1976). Nerve conduction studies and electromyography in Friedreich's Ataxia. Can. J. Neurol. Sci. 3, 313-317.

PLAITAKIS, A., BERL, S., NICKLAS, W.O. and YAHR, M.D. (1980b). Glutamate dehydrogenase deficiency in spinocerebellar degenerations: correlation with adult-onset recessive ataxia. Ann. Neurol. 8, 129-130.

PLAITAKIS, A., NICKLAS, W.J, and BERL, S. (1979). Alterations in uptake and metabolism of aspartate and glutamate in brain of thiamine deficient animals. Brain Res. 171, 489-502.

PLAITAKIS, A., NICKLAS, W.J. and DESNICK. R.J. (1980a). Glutamate dehydrogenase deficiency in three patients with Spinocerebellar syndrome. Ann. Neurol. 7. 297-303.

PRINEAS. J.B. (1969). The pathogenesis of dying-back polyneuropathies. II ... An 
ultrastructural study of experimental acrylamide intoxication in the cat. J. Neuropathol. Exp. Neurol. 28, 598-621.

RASSIN. D.K.. STURMAN. J.A. and GAULL. G.E. (1980). Taurine and glutamate: developmental interrelationships in monkey brain. Am. Soc. Neurochem. Proc. 11. 70.

REA, M.A. and McBRIDE, W.J. (1978). Effects of $x$-irradiation on the levels of glutamate, aspartate and GABA in different regions of the cerebellum of the rat. Life Sci. 23. 2355-2360.

REED, C.F. (1968). Phospholipid exchange between plasma and enthrocytes in man and the dog. J. Clin. Invest. 47, 749-760.

REMTULLA, M.A., KATZ, S, and APPLEGARTH, D.A. (1979). Effect of taurine on passive ion transport in rat brain synaptosomes. Can. Fed. Biol. Soc. Proceed $22,80$.

RENOOIJ, W. and VAN GOLDE, L.M.G. (1977). The transposition of molecular classes of phosphatidyl choline across the rat erythrocyte membrane and their exchange between the red cell membrane and plasma lipoproteins. Biochim. Biophys. Acta 470 , 465-474.

ROBINSON, N. (1968). Chemical changes in spinal cord in Friedreich's Ataxia and motor neurone disease. J. Neurol. Neurosurg. Psychiat. 31, 330-333.

RODRIGUEZ-BUDELLI, $M$. and KARK, P. (1978). Kinetic evidence for a structural abnormality of lipoamide dehydrogenase in two patients with Friedreich's Ataxia. Neurology 28, 1283-1286.

RODRIGUEZ-BUDELLI, $M$. and KARK, R.A.P. (1979). Heat-lability of enzyme in lipoamide dehydrogenase-deficiency Friedreich's Ataxia. Clin. Res. 27, 52A.

SANCHEZ-CASIS, G., COTE, $M$, and BARbeaU, A. (1976). Pathology of the heart in Friedreich's Ataxia: Review of the literature and report of one case. Can. $\mathbf{J}$. Neurol. Sci. 3, 349-354.

SANTIAGO, E., LOPEZ-MORATALIA, N. and SEGOVIA, J.L. (1973). Correlation between losses of mitochondrial ATP ase activity and cardiolipin degradation. Biochem. Biophys. Res. Comm. 53, 439-445.
SCHOENTAL, R. and CAVANAGH, J.B. (1977). Mechanisms involved in the "dyingback" process - an hypothesis implicating coenzymes. Neuropathol. Appl. Neurobiol. 3. 143-147.

SEAMAN, G.V.F., SWANK, R.F. and ZUKOSKI. C.F. (1979). Red cell membrane differences in multiple sclerosis are acquired from plasma. Lancet 1, 1139.

SEAMAN, G.V.F., SWANK, R.L. and TAMBLYN, C.H. (1980). Plasma origin of red-cell-membrane changes in multiple sclerosis. Lancet 1, 938.

SHAPCOTT, D., MELANCCON, S., BUTTER WORTH, R.F., KHOURY, K., COLLU, R., BRETON, G., GEOFFROY, G., LEMIEUX, B. and BARBEAU, A. (1976). Glucose and insulin metabolism in Friedreich's Ataxia. Can. J. Neurol. Sci. 3, 361-364.

SHUKLA, V.K.S., EGESKOV JENSEN, G. and CLAUSEN, J. (1978). Serum fatty acids and peroxidase abnormalities in Batten's disease. Res. Exp. Med. (Berl) 173, $27-34$.

SPENCER, P.S., SABRI, M.I., SCHAUMBURG, H.H. and MOORE, C.L. (1979). Does a defect in energy metabolism in the nerve fiber underlie axonal degeneration in polyneuropathies? Ann. Neurol. 5, 501-507.

STEINBERG, M.S., MAGNANI, J., CZARKOWSKI, N., COCCIA, M.B. and BARBEAU, A. (1979). Hemagglutination by lectins in Friedreich's Ataxia. Can. J. Neurol. Sci. 6, 229-309.

STUMPF, D.A. and PARKS, J.K. (1978). Friedreich's Ataxia: I. Normal Pyruvate dehydrogenase complex activity in Platelets. Ann. Neurol. 4, 366-368.

STUMPF, D.A. and PARKS, J.K. (1979). Friedreich's ataxia II - Normal kinetics of lipoamide dehydrogenase. Neurology 29 , 820-826.

STUMPF, D.A. and PARKS, J.K. (1980). Urea cycle regulation: I Coupling of ornithine metabolism to mitochondrial oxidative phosphorylation. Neurology 30, 178-184.

THOREN, C. (1962). Diabetes mellitus in Friedreich's Ataxia. Acta Paediat. 51 (suppl 135), 239-247.

TRONCOSO, J.C., CORK, L.C., STEINBERG,
H.S., DICARLO, C. and PRICE, D.L. (1980). Inherited Ataxia in Gordon Setters. Neurology 30, 440.

TYSON, C.A., VANDE ZANDE, $H$. and GREEN, D.E. (1976). Phospholipids as Ionophores. J. Biol. Chem. 251, 1326-1332.

VERONESI, B., PETERSON, E.R., DI VINCENZO, G., SPENCER, P.S. and SCHAUMBURG, H.H. (1978). A tissue culture model of distal (dying-back) axonopathy - its use in determining primary neurotoxic compounds. J. Neuropathol. Exp. Neurol. 37, 703.

WALKER, J.L., CHAMBERLAIN, S, and ROBINSON, N. (1980a). Lipids and lipoproteins in Friedreich's Ataxia. J. Neurol. Neurosurg. Psychiat. 43, 111-117.

WALKER, J.L., CHAMBERLAIN, S, and ROBINSON, N. (1980b). Failure to detect abnormal fatty acid profiles in serum lipoproteins in Friedreich's Ataxia. Ann. Neurol. 8, 74-76.

WASTIAUX, J.P., LAMOUREUX, G., BOUCHARD, J.P., DURIVAGE, A., BARBEAU, C. and BARBEAU, A. (1978). HLA and complement typing in olivoponto-cerebellar atrophy. Can. J. Neurol. Sci. 5, 75-81.

WATKINS, J.C. NMDA Receptors - New light on amino acid-mediated synaptic excitation. Trends in Neurosciences March 1980, pp. 61-64.

WILLIAMS, L.L. (1979). Pyruvate oxidation in Charcot-Marie-Tooth disease. Neurology 29, 1492-1498.

YANAGAWA, H. and EGAMI, F. (1975). Effects of asparagusate and lipoate on enzymes of the tricarboxylic acid cycle and related metabolic pathways. J. Biochem. 78 , $1153-1160$

YAO, J.K., ELLEFSON, R.D. and DYCK, P.J. (1976). Lipid abnormalities in hereditary neuropathy: Part 1. Serum non-polar lipids. J. Neurol. Sci. 29, 161-175.

YAO, J.K. and DYCK, P.J. (1978). Lipid abnormalities in hereditary neuropathy Part 2. Serum phospholipids. J. Neurol. Sci. 36, 225-236. 